\title{
Reconciling Contracts and Relational Governance through Strategic Contracting
}

Petersen, Bent; Østergaard, Kim

\author{
Document Version \\ Accepted author manuscript \\ Published in: \\ Journal of Business and Industrial Marketing \\ DOI: \\ 10.1108/JBIM-09-2016-0223 \\ Publication date: \\ 2018 \\ License \\ Unspecified
}

Citation for published version (APA):

Petersen, B., \& Østergaard, K. (2018). Reconciling Contracts and Relational Governance through Strategic Contracting. Journal of Business and Industrial Marketing, 33(3), 265-276. https://doi.org/10.1108/JBIM-092016-0223

Link to publication in CBS Research Portal

\section{General rights}

Copyright and moral rights for the publications made accessible in the public portal are retained by the authors and/or other copyright owners and it is a condition of accessing publications that users recognise and abide by the legal requirements associated with these rights.

\section{Take down policy}

If you believe that this document breaches copyright please contact us (research.lib@cbs.dk) providing details, and we will remove access to the work immediately and investigate your claim.

Download date: 26. Apr. 2023

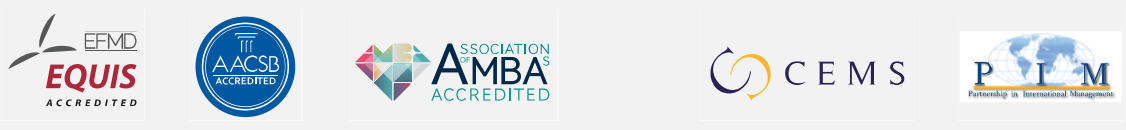




\title{
Reconciling Contracts and Relational Governance through Strategic Contracting
}

\author{
Bent Petersen and Kim Ostergaard
}

Journal article (Accepted manuscript*)

\section{Please cite this article as:}

Petersen, B., \& Ostergaard, K. (2018). Reconciling Contracts and Relational Governance through Strategic Contracting. Journal of Business and Industrial Marketing, 33(3), 265-276. 00I: 10.1108/JBIM-09-2016-0223

\section{DOI: 10.1108/JBIM-09-2016-0223}

This article is [? Emerald Group Publishing and permission has been granted for this version to appear here: https://research.cbs.dk/en/publications/reconciling-contracts-and-relational-governance-through-strategic.

Emerald does not grant permission for this article to be further copied/distributed or hosted elsewhere without the express permission from Emerald Group Publishing Limited.

* This version of the article has been accepted for publication and undergone full peer review but has not been through the copyediting, typesetting, pagination and proofreading process, which may lead to differences between this version and the publisher's final version AKA Version of Record. 


\title{
Reconciling Formal Contracts and Relational Governance through Strategic Contracting
}

\author{
Bent Petersen ${ }^{1}$ \\ Copenhagen Business School
}

Kim Østergaard

University of Southern Denmark

\footnotetext{
${ }^{1}$ Corresponding author.

Contact details:

Copenhagen Business School

Kilevej 14A, $2^{\text {nd }}$ floor, Room 2.59

DK-2000 Frederiksberg

Office telephone: +4538152510

Mobile phone: +45 30899598

Email: bp.smg@cbs.dk
} 


\begin{abstract}
Purpose - In an industrial marketing context of manufacturer-distributor collaboration this law \& economics article aims to contrast two approaches to contracting: conventional and strategic.

Design/methodology/approach - Based on relational rent theory the article provides an analytical framework for juxtaposing conventional and strategic contracting. A contingency approach is applied in order to formulate propositions as to when conventional versus strategic contracting is preferable.
\end{abstract}

Findings - The distinction between conventional and strategic contracting has implications as to whether relational governance substitutes or complements formal contracts (the substitution versus complements perspectives). Strategic contracting results in complementarity (rather than substitutability) between formal contracts and relational governance.

Research limitations/implications - The article argues that a more nuanced view on contract types, such as strategic versus conventional, may reconcile the enduring research controversy between the substitution and complements perspectives.

Practical implications - Today, formal contracts with foreign distributors tend to resemble "prenuptial agreements”. The opportunity for relational rent (e.g. manifested in higher export revenues) grows if conventional contracts are superseded by contracts following strategic contracting principles.

Originality/value - The study is interdisciplinary, not only by its combination of marketing, management and contractual economics, but also through its law \& economics amalgamation.

Key words Law \& Economics, Proactive law, Strategic contracting, Foreign intermediaries Paper type Conceptual paper 


\section{Reconciling Contracts and Relational Governance through Strategic Contracting}

\section{Introduction}

In today’s dynamic and ever-changing international business environment, intermediary contracts governing, for example, commercial agencies, distributorships, and franchises have generally remained remarkably immutable. Most intermediary contracts are still best described as "prenuptial agreements" with the primary objective of stipulating the conditions for dissolution of the cooperation. These “conventional” contracts primarily regulate how disputes are settled, and how tangible and intangible assets are to be divided between the parties in the case of dissolution. The trust building that lubricates business transactions is therefore something which mainly takes place besides - and perhaps even despite - the formal contract. This separation echoes the distinction between formal contracts and relational governance that goes back to Macauley (1963) and Macneil (1978; 2000) where relational governance has received more attention in the industrial marketing literature (e.g. Ehret and Haase, 2012; Mouzas and Blois, 2013; Möhring and Finch, 2013; Yang et al., 2017). As succinctly expressed by Möhring and Finch (2013: 406): “Contracts are under-researched in business-to-business marketing, which is remarkable given their ubiquity in practice. This may be due to contracts being often in the background of the more prominent research areas of relationships and interaction.” It is probably no exaggeration to say that classical and neoclassical contract theory (Klein et al. 1978; Williamson, 1985; Joskow, 1988) in general has a bad reputation among industrial marketing scholars inasmuch as it by denying a relational paradigm “[...] is bound to remain out of touch with reality and riddled with fiction and thus fail to explain precisely what it sets out to explain.” (Kimel, 2007:250). The asserted 
disconnection between the formal contract and the relational capabilities of the parties is by no means a viewpoint that only takes prevalence among industrial marketing scholars. It also finds recognition in the general management and organizational behavior literature. As an example, Dyer and Singh (1998) in their seminal article on relational rent claim that trust-building is a process preceding contracting. Also, other management and organizational behavior scholars (e.g., Bradach and Eccles, 1989; Gulati, 1995; Adler, 2001) have argued that trust and reputation is much more important for the effective functioning of inter-organizational relationships than is the formal contract. Still, Poppo and Zenger (2002) in their empirical study challenge the 'substitution perspective’ asserting that relational norms, such as trust, are substitutes for formal contracts (and vertical integration). Rather than hindering or substituting for relational governance, "well-specified contracts may actually promote more cooperative, long-term, trusting exchange relationships” (Poppo and Zenger, 2002:708). The 'complements perspective' proposes that the combined use of contracts and relational governance promotes cooperation (Poppo and Zenger, 2002). By specifying contractual safeguards, parties signal their intent to behave cooperatively, thus facilitating the development of relational norms. Likewise, because contracts are necessarily incomplete, relational norms and trust foster "continuance and bilateralism when change and conflict arise” (Poppo and Zenger, 2002: 713). More recent studies have also indicated that contract structure and relational characteristics are complements (Dyer and Chu, 2003; Hoetker and Mellewigt, 2009; Li et al., 2010; Mellewigt et al., 2007; Yang et al., 2017).

In this article we adopt and further develop the perspective that "well-specified" contracts complement rather than hinder relational governance, including trust-building. Formal contracts work when they aim to preserve what is important in the relational substance (Stinchcombe, 2001; Mouzas and Ford, 2012). The complementarity essentially depends on the design of the formal contract and, as 
we shall show, the process of selecting the contract partner. Evidently, conventional contracts that take the form of being prenuptial agreements hinder, rather than complement relational governance. This in contrast to strategic contracts - by which we refer to a new set of contract principles that have emerged under the law-school labels of proactive law (Berger-Walliser, 2012; Haapio, 1998) and strategic contracting (DiMatteo, 2010). Strategic and proactive contracting focus on value creation (Bowman and Ambrosini, 2000), relational rent generation (Dyer and Singh, 1998), and prevention of conflicts rather than on value appropriation and reactive, third-party conflict resolution. By adopting the contracting principles of preventing rather than settling disputes and of creating rather than appropriating value, firms may achieve a competitive edge.

However, bringing about a rupture with old, widely accepted contracting practices is not an easy feat. New contracting practices require a change of mindset among lawyers as well as business managers. Some legal scholars (e.g. Berger-Walliser, 2012; DiMatteo et al., 2012) even talk about a need for a paradigm shift in the business community. That might be true to the extent that contract practices seem unaffected by numerous calls for channel partnerships voiced by marketing management scholars over the past many years (McVey, 1960; Webster, 1976; Reddy and Marvin, 1986; Karanuratna and Johnson, 1997; Walter et al., 2003). These calls point to an untapped potential to earn extra export sales revenue by applying the principles of strategic and proactive contracting to the use of foreign intermediaries.

We outline these principles along several contract dimensions: choice of intermediary, collaborative basis, commercial risk allocation, commitment, and conflict resolution. For each of these dimensions, we aspire to clarify the differences between conventional and strategic contracting. Hence, the aim of this study is to guide marketing managers into beneficial contracting with intermediaries by pointing to some very distinct and consequential differences between the two contract types. 
With this background the article proceeds as follows. In the next section (section 2), we outline the subject matter and business marketing context of the study. Section 3 accounts for the various perceptions of the manner in which the contract is drafted and how conventional and strategic contracting is defined in the interdisciplinary intersection between law and economics. In the ensuing section 4, we highlight the differences between conventional and strategic contracting with intermediaries. We focus on five contract dimensions in which the differences between the two approaches are particularly notable. In section 5 we formulate propositions regarding the circumstances that favor the use of either conventional or strategic contracting with intermediaries. Section 6 concludes, highlights managerial implications and points to future research opportunities.

\section{The subject matter and context of the study}

The marketing management setting of this law and economics study is manufacturers' use of intermediaries to promote and sell their products to other firms or to households in foreign markets, and, in some cases, to provide logistics and aftersales services to these customers. Furthermore, we focus on situations in which the collaboration between the manufacturer and its intermediary is governed by a written agreement, which we henceforth referred to as an "intermediary contract”. We use "intermediary contract" as a generic term for the contracts that manufacturers enter into with such actors as commercial agents, intermediaries, representatives, distributors, export houses, franchisees, and lessees.

Intermediary contracts are widely used by export firms (Karanuratna and Johnson, 1997;

Petersen et al., 2000; Li, 2003; Ellis, 2005; Zhang et al., 2003; Skarmeas et al., 2008), and the use of an intermediary often precedes a company’s establishment of its own subsidiary (Johanson and Vahlne, 
1977). Intermediaries are typically used to build up critical mass in foreign markets. However, in particular risky or small markets, intermediaries also appear as permanent modes of operation.

The intermediary contract stipulates the rights and responsibilities of the two parties: the manufacturer (also referred to as the supplier, producer, principal, franchisor, or lessor) and the intermediary. Ideally, the contract should align the interests of the two parties by putting the right incentives in place (Karanuratna and Johnson, 1997; Sharma and Sheth, 1997; Naude and Buttle, 2000; Samiee and Walters, 2003). However, this is easier said than done. The literature provides ample evidence suggesting that the use of intermediaries is fraught with difficulties due to the misaligned interests of the contract parties (Wathne and Heide, 2000; Ellis, 2005; Leonidou et al., 2006; Petersen et al., 2006; Tsay and Agrawal, 2004;). Occasionally, these conflicts are reported in the business media. The losses resulting from contractual disputes can be considerable. In cases where disputes lead the manufacturer to terminate without notice, the manufacturer not only incurs "take-down" and "setup” costs (Weiss and Anderson, 1992) but also forsakes future sales revenue. In emerging markets, such contract terminations may be fatal to the extent that the temporary market exit allows competitors to achieve first-mover advantages (Lieberman and Montgomery, 1988) and, in the worst case, preempt the market. To make things worse, the dramatic disputes that garner the attention of the media are presumably only the tip of the iceberg. When contractual alignment of manufacturer-intermediary interests is lacking, sales revenue may be affected in more discrete ways if intermediaries deliberately underperform due to perceived holdup risks (Ellis, 2005; Petersen et al., 2006; Welch et al., 2007). There are numerous reasons to believe that incurred indemnification and compensation costs are dwarfed by revenue losses resulting from intermediary underperformance. When we later specify the differences between strategic and conventional contracting we choose to focus on distributors and distributor contracts as archetypical for intermediaries. A distributor acts in its own name, for its own 
account, and at its own risk. Normally, the distributor buys the product in question and resells it either through a physical outlet or online. The legal starting point between the manufacturer and the distributor is the principle of "freedom of contract". This principle implies that the parties in question can decide whether to enter into a contract and that they can choose the contents of the contract. The use of strategic contracting should not give rise to any particular new problems in relation to competition law.

\section{Juxtaposing and defining conventional and strategic contracting}

Our approach to defining "conventional” and "strategic” contracting is based on our interest in how the marketing management literature can enrich legal thinking in general and the writing of intermediary/distributor contracts, specifically. In the field of law, notions like "traditional” and "strategic" contracting have emerged in order to characterize the way in which contracts are written. Berger-Walliser (2012: 23) describes traditional contracting in the following way: "From the perspective of proactive law, traditional contracts are often reactive focusing on legal problems and litigation instead of serving as a management tool and to foster collaboration between business partners, though the latter is crucial for success in today’s global and networked economy.” In our view, conventional contracting has the reactive approach in common with traditional contracting, but in addition to this conventional contracting is heavily focused on the transfer of risks and liability to the other party with the aim of maximizing own returns. Basically, the conventional contract serves as an insurance that, at best, prevents the other party from making a claim even if there is obviously a breach of contract. DiMatteo et al. (2012: 106) express this focus on risk renunciation in the following manner: "Business managers and their lawyers need to shift towards a proactive, strategic method of contracting. This entails preventing contract drafters and users of contracts from continuing to do what 
they have always done - that is, assuming that business persons do deals, negotiate the deal terms, and secure business success, and their lawyers write one-sided contracts with legal terms that attempt to allocate risk to the other party and protect their clients in case of a failure or dispute.”

In contrast to traditional and conventional contracting strategic contracting appears as a source of competitive advantage: "Contracts can be strategic in obtaining a competitive advantage, or they can be a tool to support collaboration by minimizing the opportunities for advance taking.” (DiMatteo, 2010: 729). DiMatteo’s strategic view on contracting as bridging law and competitive advantage is shared by several other legal scholars (e.g., Bird, 2009; Bagley, 2010) and the following two comments also call for applying a strategic approach to contracting: "The contracting process itself will test the resilience of the organization and its alignment with the market by ensuring that the core value propositions are supported by performance capabilities or that strategic business goals are not undermined by the wrong form of relationship.” (Cummins 2015: 11). “Strategic forms a keyword referring to the idea that contracting and negotiations must serve long-term strategy and hence play a crucial strategic function.” (Pitsis et al., 2015: 3). The long-term objective of strategic contracting is to achieve joint competitive advantage for the contract parties. As a supplement to these characteristics of strategic contracting, we point to the importance of resource complementarity and strategic fit between the contract parties (Dyer and Singh, 1998). Furthermore, the parties need to include contract clauses that safeguard knowledge exchange and relationship-specific investments.

Proactive provisions enhance and support the fulfillment of strategic contracting. We see proactive contracting as agreements made with instruments that effectively prevent or resolve tensions and disagreements before they escalate to unequivocal conflicts. In strategic contracting, the contents will entail a balance between proactive and reactive provisions whereas in conventional contracting the contents of the contract are solely based on reactive provisions. Provisions about knowledge exchange 
and relationship-specific investments will, in essence, have to be proactive in order to secure the dynamics and the long term condition of the relationship.

Based on the above, we view conventional contracting as characterized by the aim of own profit maximization (at the expense of the other contract party, if necessary) through the use of reactive and not proactive provisions. The primary objectives of those provisions are: (i) to transfer risks and undertakings to the other party; (ii) to regulate how disputes are settled; (iii) to stipulate conditions for the dissolution of the collaboration and (iv) to stipulate how assets are to be divided between the parties if the collaboration is dissolved. In other words, value appropriation, and not value creation, is the main concern. In economic terms, a conventional contract associates with an arm’s-length transaction rather than a strategic partnership.

In contrast, we view strategic contracting as characterized by the aim of generating relational rent through the use of both proactive and reactive provisions that, based on resource complementarity and strategic fit between the contract parties, protect knowledge exchange and relationship-specific investments from opportunistic behavior. Hence, a strategic contract is a partnership arrangement through which the contracting parties aim to achieve joint competitive advantage.

\section{Dimensions by which conventional and strategic contracting differ}

In the following, we account for the differences between conventional and strategic contracting with foreign intermediaries using archetypes of contracting. For expository reasons, we describe conventional and strategic contracting in somewhat extreme forms. However, we are aware that in the practical world of international trade, most contracts and contracting processes presumably are "hybrids" of the two contracting/contractual archetypes. 
Our discussion of the differences is broken into five parts based on the aforementioned contracting dimensions. While we acknowledge that other dimensions of the contract are relevant and worthy of consideration, we focus on these five dimensions because they specifically serve to differentiate conventional and strategic contracting.

The first dimension - the choice of intermediary - is not part of the contract design per se. However, as it is an important antecedent of contracting that effects the other dimensions, including effective governance, we consider its inclusion to be relevant.

\subsection{Choice of intermediary}

A basic premise of strategic contracting is that the chosen intermediary is, in all likelihood, the best possible intermediary in the market. This implies that the intermediary has the necessary enthusiasm and valuable complementary assets, that a basic level of trust and other relational norms can be ascertained, and that the intermediary also fits strategically with the manufacturer (see also the next sub-section on strategic fit). Given these premises, there is little need to incorporate conditions for dissolution of the cooperation or to stipulate how the assets should be divided between the parties if the relationship is dissolved. This can be contrasted with the choice of intermediary associated with conventional contracting. In that case, the manufacturer's search effort preceding the drafting of the contract is limited. In fact, the intermediary often chooses the manufacturer rather than vice versa (Cavusgil et al., 1995). Hence, in a typical scenario, the intermediary may approach the manufacturer at a trade fair, and offer the manufacturer its marketing and sales services for use in a new, foreign market. 
Nonetheless, manufacturers do not assign distributorships to completely random candidates, especially if a distributorship carries territorial exclusivity. Some basic criteria - such as industry experience, a solid financial basis, and good market coverage - must be fulfilled. However, conventional contracting does not aim to find the best possible candidate - just an acceptable one. In other words, the choice of intermediary is a matter of satisficing (Simon, 1956) rather than optimizing. A search effort that only aims to find an acceptable candidate has a consequence - the manufacturer will not know if better alternatives are available or if the intermediary might fail to contribute the effort needed for a market breakthrough. Given this uncertainty, the manufacturer naturally wants a contract that allows for relatively fast and costless cancellation of the cooperation. In this regard, we highlight the two-way causality between search effort and contract design: careless selection of intermediaries creates a compelling need for contracts that facilitate smooth replacement in the case of nonperformance. Conversely, the availability of such contracts encourages careless selection. As conventional contracts facilitate smooth replacement of appointed intermediaries, the manufacturer faces little risk in subscribing to a first-come, first-hired selection principle. The cost of learning by experience appears to be fairly low, although it is higher in reality than it might appear. Furthermore, conventional contracts have performance-based remuneration as an enshrined self-selection principle. To the extent that sales in the local market can only be obtained through qualified effort, performancebased remuneration should, in principle, scare away unqualified candidates (Bergen et al., 1992). However, this assumes that windfall gains will not occur - an assumption that is often incorrect due to outreach customers, word-of-mouth, and reputational effects. In other words, the self-selection principle is rarely a foolproof guarantee against unqualified contenders. Nonetheless, self-selection has the irrefutable advantage of imposing zero or close to zero search costs on the manufacturer. 
More proactive search methods, such as signaling and screening (Bergen et al., 1992), do not economize on search costs to the same extent as self-selection. Screening, in particular, can be quite costly, as it usually implies personal interviews with shortlisted candidates, as well as on-site inspections of the premises and distribution networks of prospective intermediaries. When the candidates are domiciled in distant locations, the use of screening may be both bothersome and timeconsuming. Nevertheless, screening and signaling are prerequisites for a successful implementation of strategic contracting. When it comes to strategic contracting, manufacturers need to know that candidates that are better qualified and motivated than the appointed intermediary do not exist in the foreign territory. This is because replacement is not an option in a long-term, unique relationship with an intermediary. This highlights the fact that strategic contracting is only relevant when it comes to exclusive and selective distribution.

Given this discussion, conventional and strategic contracting is preceded by quite different approaches to the choice of intermediaries. Conventional contracting is designed in anticipation of the termination and replacement of the intermediary. In other words, the conventional intermediary contract mitigates the risk associated with careless selection. Hence, potential search and take-down costs (Weiss and Anderson, 1992) are minimized. Strategic contracting, in contrast, is designed under the assumption of careful intermediary selection (using both signaling and screening) and in anticipation of a long-lasting collaboration. Table I summarizes the objectives and the means of intermediary selection for conventional and strategic contracting.

\footnotetext{
*** Insert Table I about here ****
} 


\subsection{Collaborative basis}

The collaborative basis for conventional contracting is goal congruence in terms of expected sales in the intermediary’s territory. The manufacturer and the intermediary agree on the minimum goals for sales and sales growth per year over a defined time span. In principle, the parties collaborate in order to achieve the expected sales but, in practice, reaching the minimum sales goal stipulated in the contacted is the sole responsibility and focus of the intermediary. Accordingly, redeemable clauses in the contract state that the intermediary must fulfil the sales expectations and that if it fails to do so, it risks termination without notice.

Goal congruence in terms of expected sales may also occur in strategic contracting, but it is always accompanied by a business plan developed by the contract parties together. The development of the business plan is, in itself, and opportunity for the parties to establish relational norms, including a basic level of trust (Zaheer and Venkatraman, 1995; Dyer and Singh, 1998). The joint business plan specifies how the expected sales should be achieved. It may, for example, describe which resources should be deployed, by whom, and when. The business plan exposes the choice of generic competitive strategy (Porter, 1980). It also defines the targeted customer segments in the local market and the marketing mix. General and vague declarations about the warranted sales effort of the intermediary, such as: "The intermediary shall up to the best of his/her effort, promote and market the products in the territory” ${ }^{1}$, are insufficient on their own. In strategic contracting the undertakings of the manufacturer are spelled out clearly. The business plan becomes an integral part of the strategic contract in which the main elements of the plan are stated up front (with implementation details included in an addendum to the contract).

The joint business plan presupposes - and manifests - a strategic fit between the manufacturer and the intermediary. It is important to keep in mind that strategic fit infers goal congruence, but goal 
congruence does not necessarily imply strategic fit. Therefore, the contract parties may agree on the sales budget (as in conventional contracting) but they may not necessarily agree on how the expected sales should be realized. In other words, strategy and strategic fit are not goal setting (e.g. formulation of expected sales in the local market). Rather, they encompass a set of coherent actions focused on how the goals should be achieved (Rumelt, 2011).

In summary, the collaborative basis of conventional contracting is goal congruence in relation to the intermediary's expected sales, and failure to meet those goals can result in the introduction of agreed remedies. In contrast, the collaborative basis of strategic contracting is the strategic fit as expressed in the joint business plan as well as the relational norms that are established during the planning process.

\subsection{Commercial risk allocation}

The economic argument for risk allocation is that a strategically stipulated contract should allocate each risk to the party most capable of bearing that risk (Shavell, 1979; Triantis, 2000). Principal/agent theory assumes that the principal is risk neutral and the agent is risk averse (see, e.g., Eisenhardt, 1989). The theory also argues that differences in risk tolerance (or preference) are based on the general assumptions that the principal practices business diversification (thereby spreading its risks), while the agent is dependent on only one or a few businesses. In the extreme case, an agent does businesses with only one principal.

Export intermediaries are usually remunerated according to their sales performance. Therefore, behavior-based compensation is the exception to the general rule of outcome-based compensation (Anderson and Oliver, 1987). Hence, conventional contracting implicitly assumes that the intermediary is the party most capable of bearing the commercial risk associated with the transaction. This might be 
so in some cases, such as when the intermediary is a large distributor that serves numerous, small manufacturers. More often, however, the intermediary is dwarfed by its principals. For example, large multinational fast-food franchisors, such as McDonald's, KFC, and Taco Bell, are in a much better position to bear risk than their local franchisees. Therefore, by insisting on outcome-based remuneration for intermediaries, conventional contracting disregards the economic argument of risk allocation based on the risk preferences of the contract parties. Instead of pursuing rational risk allocation, conventional contracting apparently aims to minimize the risk of the manufacturer. This insistence on allocating risk to the intermediary most likely comes at a cost - the cost of the risk premium commanded by the intermediary as compensation for bearing the risk. The risk premium arguably rises with the degree of the intermediary's risk aversion. Nonetheless, there might be good reasons not to alleviate all risks for the intermediary, even in cases in which the manufacturer is the more risk-willing contract party. One reason is that outcome-based remuneration provides an agent with a stronger incentive than behavior-based compensation to undertake his tasks whole-heartedly see, for example, Fernie and Metcalf (1996) and Kahn and Sherer (1990) for empirical evidence. In addition, finding the right risk balance is, in reality, quite complicated: the contract parties may not know their true risk preferences from the outset and risk allocation is likely to be highly dependent on probability estimates (DiMatteo et al., 2012). Furthermore, behavior-based remuneration might be an option fraught with measurement difficulties (Anderson and Oliver, 1987). Lastly, the acceptance of risk serves as a signal of commitment to the relationship, and this signaling value has to be taken into the equation when considering optimal risk allocation (Spence, 1973).

Given these reservations, our main conclusion is that strategic contracting pursues a risk allocation that reflects the risk preferences of the contract parties. In cases in which the intermediary appears to be the more risk-averse party, the manufacturer should offer a contract with full or partial 
behavior-based remuneration in order to protect the intermediary against exogenous commercial risks, such as economic recession; non-approval of products; increases in taxes, levies, or tariffs; and trade embargoes.

\subsection{Commitment}

Conventional contracting is characterized by limited commitment from the manufacturer. Rather than credible commitment (Williamson, 1983), the conventional contract signals credible threats of relationship termination by, for example, ensuring trademark protection, removing the possibility for compensation for the intermediary in cases of termination with or without notice, or insisting on a litigation venue in the manufacturer's home country. The above-mentioned passing of commercial risks associated with adverse market factors onto the intermediary also signals a lack of commitment to the relationship. The manufacturer's lack of commitment follows logically from the fact that the manufacturer can replace the intermediary at the lowest possible cost, as we alluded to our discussion of the choice of intermediary. In contrast, strategic contracting implies the manufacturer's full commitment to the collaboration as a prerequisite for commitment from the intermediary. The overall aim of strategic contracting - value creation (Bowman and Ambrosini, 2000) - is mainly to be achieved through relationship-specific investments, which are strongly correlated with commitment (Chen et al., 2017).

A manufacturer can directly and indirectly commit to collaboration with an intermediary. A direct commitment occurs when the manufacturer undertakes relationship-specific investments. As intermediaries are more likely than manufacturers to make relationship-specific investments (manufacturers' investments tend to be specific to the foreign market rather than to the relationship), manufacturers can show direct commitment by offering co-financing. They can, for example, share the 
costs of trade-fair participation, or participate in the training and education of the intermediary's sales force. There have also been examples of manufacturers that pay the salary (or some of it) of a sales person formally employed by the intermediary but fully dedicated to the marketing and sales of the manufacturer’s products (Petersen, 1996; Weiss and Kurland, 1997).

The manufacturer can also indirectly commit to the collaboration with the intermediary by safeguarding the intermediary’s relationship-specific investments. The intermediary needs to be protected against all three types of threats that could keep the intermediary from receiving a payoff from its relationship-specific investments: adverse exogenous factors (as mentioned above), contenders' free-riding, and holdup by the manufacturer. The safeguard against unfortunate events in the local business environment that are beyond the control of the intermediary is behavior-based remuneration. The protection against free-riding by competing, local firms is also straightforward - the manufacturer can grant a distributorship to only one intermediary within a certain territory. This territorial exclusivity shuts off other distributors that might otherwise be tempted to free-ride on the product and brand recognition that the groundbreaking intermediary creates through manufacturerspecific investments. A similar simple protection formula does not apply to the holdup risk assumed by intermediaries that make non-reciprocal relationship-specific investments. ${ }^{2}$ Holdup safeguards (Klein, et al., 1978) may take many forms. Among the more obvious protective mechanisms are lengthy or irrevocable contracts (Petersen et al., 2006), offsetting investments in customer loyalty (Heide and John, 1988), and severance payments (Anderson and Weitz, 1992). Other holdup safeguards include real options (Gorovaria and Windsperger, 2013), private (i.e. the intermediary’s own) labeling (Weiss and Kurland, 1997), and self-disclosure (Crosby et al., 1990).

In conclusion, strategic contracting is about mutual commitment to dedicated, long-term collaboration. Conventional contracting is also about commitment, but only on the part of the 
intermediary. The conventional intermediary contract aims to minimize the manufacturer's "takedown” costs (Weiss and Anderson, 1992) in the case of termination. This non-commitment on the manufacturer's side constitutes a credible threat of termination, which - all else being equal discourages the intermediary from undertaking relationship-specific investments of any significance.

\subsection{Conflict resolution}

In the law \& economics literature there is a distinction between private ordering (self-enforcing contracts) and third-party ordering (typically court or arbitration decision) aimed at achieving effective governance. With regard to deriving relational rent Dyer and Singh (1998) suggest that private ordering is superior to third-party ordering because the former implies lower transaction costs. Whether private ordering completely leaves out the use of a formal contract is, however, an open question. Even though a formal contract imposes transaction costs ex ante, it usually also reduces transaction costs ex post. This generally supports the idea in strategic contracting that a contract not only serves as a legal document but also as a means to prevent that tensions and disagreements between the parties escalate into outright conflicts. In strategic contracting the contract parties can decide to leave out provisions about liabilities and remedies that are standard in conventional contracting and instead include various proactive provisions or "remedies". Hence, conventional and strategic contracting differs in their reliance on reactive and proactive provisions, respectively.

In order to enhance the fulfillment of the contract and escape conflicts, an important proactive provision deals with the mutual obligation to communicate. Even though such an obligation imposes transaction costs, these costs may be well spent insofar as lack of communication, or outright miscommunication, makes up major causes of litigation (IACCM, 2013/14). The joint sharing of strategic information should, ideally, support the notion of a dynamic contract in which it might be 
necessary to add riders that change the original wording. Furthermore, proactive provisions about communication might also serve as a tool for remedying bounded rationality, which results in an incomplete contract and a situation in which subsequent unexpected circumstances may affect the fulfillment of the contract. ${ }^{3}$ With the inclusion of a hardship provision in the contract the parties have the obligation to negotiate, in good faith, how the contract should be preserved - even if an unexpected circumstance is onerous. Conversely, circumstances can also create an unexpected opportunity for joint value creation that the parties did not take into consideration when entering the contract.

In addition to inclusion of proactive provisions about communication, other proactive, private ordering provisions may be brought into use as the dispute escalates towards an outright conflict. At a relatively low conflict level the parties' representatives try to solve the dispute on their own and, if necessary, add a rider to the contract. In order to prevent opportunistic behavior at this level, the contract may state that any dispute at this level must be resolved within a specified number of working days after notice of breach of contract has been given by one of the parties. If it is not possible to resolve the dispute within the stated number of working days, the dispute resolution procedure may automatically proceed to a steering committee appointed when the contract was concluded. The steering committee, consisting of representatives of both parties, has a joint obligation to resolve the dispute within a certain number of working days and in line with the principles set out at the previous dispute resolution level. If it is not possible to resolve the dispute with the aid of the steering committee, an independent mediator with knowledge of the industry may be appointed by the parties to facilitate a solution to the dispute. Only in the case that the arbitrator is unable to facilitate a settlement of the contract dispute (and a resolution through private ordering is exhausted) will the dispute procedure suggest a third party conflict resolution by litigation or arbitration; the latter either in the 
form of a national arbitration court or an international arbitration provided by, e.g., the International Chamber of Commerce.

In relation to this fifth and last contract dimension highlighted in this article - conflict resolution - we conclude that whereas conventional contracting relies mainly on reactive conflict resolution by third parties (an arbitrator, the court) strategic contracting associates with private ordering and use of both reactive and proactive provisions.

\section{Development of propositions - a contingency approach}

Our account of the differences between conventional and strategic contracting may appear somewhat lopsided to the benefit of the latter. We might have left an impression that export firms have a lot to gain from engaging in strategic contracting with intermediaries, but less so when using conventional contracting. However, conventional contracting should not automatically be associated with poor business performance. There are numerous examples of successful export ventures based on conventional contracting (although perhaps sometimes these ventures are successful more despite than because of the contracting approach). It is important to keep in mind that the commercial success of an international business relationship is determined by a number of factors other than contractual design including the salability of the exported products and personal relations among those involved in the collaboration. The importance of non-contractual determinants is underscored by the many successful export ventures that have been based on very informal agreements, such as letters of intent, memoranda of mutual understanding, or simple handshakes, all of which echo Macauley’s (1963) advice to keep lawyers at a safe distance if business collaboration is to succeed. Furthermore, the benefits of extra export sales associated with strategic contracting should be traded off against the added costs of finding 
the right intermediary and writing the contract. These transaction costs are inherently higher for strategic contracting.

The above discussion suggests that the choice between conventional and strategic contracting is not as straightforward as it may seem. Therefore, our next step is to investigate the circumstances under which one of the two archetypal contracting types will be superior to the other. The aim of this inquiry is to guide export managers in deciding when to stick with conventional contracting and when to adopt the principles of strategic contracting.

In our inquiry into the circumstances that favor one of the two contracting types, we apply a contingency approach. The contingency approach assumes that it is possible to provide managers (e.g. export managers) with guidance as to the best responses (e.g. choice of contract type) to observed contingencies. According to the contingency approach, no specific strategy can be optimal for all businesses, regardless of their infrastructure and environmental contexts. The contingency approach suggests that the relation between strategy and performance tends to be conditional, and that no universal set of strategic choices is suitable for all situations and circumstances.

As such, contingency research begins by specifying contingency variables, such as technologies (Thompson, 1967; Woodward, 1958), product characteristics (Stabell and Fjeldstad, 1998), industries (Friesen and Johnson, 1995), customer characteristics (Hunt, 1972), or competitors (Porter, 1980; McGee and Thomas, 1986), in order to categorize internal and external settings so that organizational structures and corporate strategies (including international alliance strategies, such as those involving foreign intermediaries) can be developed based on an analysis of the contingent variables. Strategy only translates into superior performance when contingent variables and strategy are properly matched (Katsikeas et al., 2006). 
Empirical inquiries adopting a contingency approach usually include three types of variables: contingency variables, management response variables, and performance variables (Zeithaml, et al., 1988). The performance variables depend on the other two types of variables - independently and in interaction (i.e. a "fit” measure). As they originate from organizational theory (Woodward, 1958), managerial-response variables have typically revolved around organizational design (Lawrence and Lorsch, 1967; Thompson, 1967) and structure (Mintzberg, 1979; Perrow, 1967). However, when the contingency approach diffused into the realms of marketing (Zeithaml et al., 1988) and strategy (Govindarajan, 1988), other management response variables emerged, such as marketing-mix standardization versus adaptation (Katsikeas et al., 2006) and differentiation versus a low-cost focus (Porter, 1980). In this article, we add another management response variable: conventional contracting versus strategic contracting.

The next step is to identify the circumstances, or contingencies, that fit either conventional or strategic contracting.

\subsection{Fit with intermediary}

Strategic contracting presupposes that the exporter is, in fact, able to find a qualified, local intermediary with whom a strategic fit is possible. This is, by no means, a given. The export manager may face a difficult dilemma if no perfect match with an intermediary in the targeted foreign market seems possible. In this case, the exporter may decide to compromise on the choice of intermediary, which tends to favor conventional contracting given the better opportunities for termination with short notice and subsequent replacement with another intermediary. Therefore, in order to make sense, strategic contracting presupposes that it is possible to find an intermediary that possesses the necessary 
complementary resources/competences and fits strategically with the manufacturer (Dyer and Singh, 1998). Hence:

P1: All else equal, strategic (conventional) contracting is the better choice when it is certain (uncertain) that the prospective intermediary is the right one.

\subsection{Sales potential}

With its higher search requirements (i.e. screening rather than self-selection) and more sophisticated governance structure (e.g. pro-active private ordering rather than third-party conflict resolution), strategic contracting is generally associated with higher upfront negotiation and drafting costs than conventional contracting. Therefore, the potential level of export sales regulated by the intermediary contract should equal an amount that justifies the fixed costs of negotiating and writing the contract. This parallels the high transaction frequency requirement of hierarchical governance structures that complements high degrees of asset specificity and uncertainty in transaction cost theory (Williamson, 1985). Therefore, entry into export markets with considerable potential calls for strategic contracting, all else equal, while conventional contracting may be more relevant for insignificant markets. Given this background, we propose:

P2: $\quad$ All else equal, strategic (conventional) contracting with an intermediary is the better choice when the sales potential of the intermediary's market is substantial (insubstantial).

\subsection{Need for relationship-specific investments}


In line with transaction cost theory, the need for relationship-specific investments, especially on the part of the intermediary, pulls in the direction of strategic contracting. In anticipation of a high degree of asset specificity as a characteristic of the relationship, the contract parties should put holdup safeguards into place. An intermediary will be very hesitant to make relationship-specific investments unless appropriate holdup safeguards are introduced, especially in situations where the sales potential of the export market exceeds the break-even point for establishment of a sales subsidiary. This is because relationship-specific investments are likely to spark sales, which, in turn, may put the intermediary at risk of being replaced by a sales subsidiary (Ellis, 2005; Petersen et al., 2006). As strategic contracting is characterized by the insertion of clauses that are intended to safeguard the intermediary against holdup (typically a termination-with-notice clause) by the manufacturer, we submit the following proposition:

P3: $\quad$ All else equal, strategic (conventional) contracting with an intermediary is the better choice when there is a need (little need) for relationship-specific investments in the intermediary's market.

\subsection{Need for knowledge exchange}

Knowledge exchange between the manufacturer and distributor is imperative for success in the market (Reddy and Marvin, 1986; Naude and Buttle, 2000; Samiee and Walters, 2003). Dyer and Singh (1998) mention knowledge exchange as a source of relational rent on a par with relationship-specific investments. Like relationship-specific investments, knowledge exchange has to be safeguarded against opportunistic behavior. Without such safeguards, the parties will be reluctant to share any useful product or market information (Reddy and Marvin, 1986). For example, foreign intermediaries are 
often unwilling to pass on information about local customers to their suppliers or manufacturers, often to such an extent that they keep the identity of these customers secret (Anderson and Weitz, 1992; Petersen, 1996). If this information is shared, the suppliers or manufacturers will be in a much better position to service the foreign market without the assistance of the intermediary because the expected “set-up costs” (Weiss and Anderson, 1992) will be limited. Conversely, manufacturers may hold back key product information in order to prevent their intermediaries from engaging in their own, local production and opportunistically skipping the manufacturer as partner (Grandinetti, 2017). Therefore, the exchange of knowledge crucial for the promotion of local sales cannot be expected unless suitable holdup safeguards are included in the contract, which is the case with strategic contracting. Therefore:

P4: $\quad$ All else equal, strategic (conventional) contracting with an intermediary is the better choice when there is a need (little need) for knowledge exchange between the parties.

\subsection{Need for risk sharing}

The risk preferences of the contract parties constitute the fifth and final contingency factor. With its insistence on outcome-based remuneration of the intermediary, conventional contracting makes economic sense based on the premise that the intermediary is the more risk-willing contract party. In other words, there is little need for the manufacturer to share some of the risk with the intermediary. This is in direct contrast to strategic contracting, which does not presuppose the risk neutrality of the intermediary but instead relies on a case-by-case approach in which the risk preferences of the contract parties are assessed and the commercial risks are shared accordingly. Hence:

P5: All else equal, strategic (conventional) contracting is the better choice when there is a need (little need) for risk sharing with the intermediary. 
*** Insert Figure 1 about here ***

Our contingency approach to the contracting choice is summarized in Figure 1. The figure shows the three types of variables: contingency variables, management response variables, and performance variables (Zeithaml et al., 1988). The contingency variables consist of five factors that characterize the foreign market and the requirements to be fulfilled if the sales potential of the market is to be released. The managerial response variables - how the marketing manager acts, given these contingencies - are condensed to a dichotomous choice between conventional and strategic contracting. In addition, some control variables ('controls'), such as the salability of the exported products and personal relations (relational norms) among those involved in the collaboration, are indicated in grey. The controls are variables that may influence performance, but only indirectly and not through the design or choice of contract. Notably, performance should not be measured in terms of intermediary performance, but rather in more general terms - like a Kaldor-Hicks type of contracting efficiency (Posner, 2007) that eventually emphasizes the business goal of the parties. Measurements of performance based on intermediary effort, generated sales, or earnings are not meaningful because these measures will always point to strategic contracting as the better choice. An effective performance measure has to take both the contracting costs and the income-generating side of the equation into consideration.

\section{Conclusions, management implications and avenues for future research}

In this article, we have contrasted conventional with strategic contracting along important contractual dimensions: choice of intermediary, collaboration basis, commercial risk allocation, commitment, and 
conflict resolution. We used a contingency approach to investigate the circumstances that impel marketing managers in exporting firms to either maintain conventional contracting practices or adopt some of the principles of strategic contracting. Our inquiry led to the formulation of a set of propositions about the fit (or, lack of fit) between contracting circumstances and the choice of a contracting mode (conventional or strategic) in which the right fit pays off in low contracting costs or high intermediary performance and, thereby, better overall performance.

Our contingency approach with the five propositions may guide marketing managers as to when conventional or strategic contracting is the more suitable choice. There is no "default" option as such: what is the best contracting choice depends on the particular circumstances. Strategic contracting obviously has its advantages in terms of stimulating relational rent, but these advantages come at higher costs of meticulous partner selection and more elaborate contract drafting. Hence, our study conveys the message to marketing managers that strategic contracting associates with careful and proactive search for, and screening of, partners. The easy access to contract termination that characterizes conventional contracting is unavailable - the partnership is binding from day one.

Our inquiry is basically conceptual. As such, it invites empirical tests of the propositions. Holdup safeguards are well-known to motivate intermediaries to engage in more committed sales efforts (e.g. Anderson and Weitz, 1992; Weiss and Kurland, 1997). However, contracting is about more than safeguarding (Schepker et al., 2013). There is an exigent need for empirical studies of the performance implications of contracting. Some key questions along these lines include: When is strategic contracting an attractive alternative to conventional contracting and what are the interaction effects of the various contract dimensions on performance? As regards the latter question, the recent study by Yang et al. (2017) emphasizes the need to study contracts and relational norms at a level disaggregated 
into the various contract dimensions. It goes without saying that marketing managers' choice of contracting principles ideally should be well-entrenched in empirical research.

Our study can also be seen as a constructive contribution to the enduring academic "controversy" between the substitution and complements perspectives. Whether or not a formal contract substitutes or complements relational governance, we argue, very much depends on the type of contract - not only in the sense of simple versus complex and detailed contracts, but also in terms of strategic contrasted to conventional contracts (as exposed in this article). Relational capabilities are much needed - and to a large extent have to supplant - the formal contract when this bears a resemblance to a "prenuptial agreement”. When a formal contract, in contrast, appears as the outcome of a strategic contracting

process it complements and even induces relational elements - thereby smoothing the functionality of complex business collaborations. So, as a final note, we submit that a more nuanced view on the type of formal contract could contribute to the reconciliation of the apparent contradiction between the substitution and complements perspectives.

\section{References}

Adler, P. (2001), “Market, hierarchy, and trust: the knowledge economy and the future of capitalism”, Organization Science, Vol. 12 No. 2, pp. 214-234.

Anderson, E, and Oliver, R.L. (1987), "Perspectives on behavior-based versus outcome-based sales force control systems”, Journal of Marketing, Vol. 51 No. 4, pp. 76-88.

Anderson, E. and Weitz, B. (1992), "The Use of Pledges to Build and Sustain Commitment in Distribution Channels”, Journal of Marketing Research, Vol. 29 No. 1, pp. 18-34.

Bagley, C.E. (2010), “What's Law Got to Do With It: Integrating Law and Strategy”, American Business Law Journal, Vol. 47, No. 4, pp. 587-639. 
Bergen, M., Dutta, S. and Walker, O.C. (1992), “Agency Relationship in Marketing: A Review of the Implications and Applications of Agency and Related Theories”, Journal of Marketing, Vol. 56 No. 3, pp. 1-24.

Berger-Walliser, G. (2012), “The Past and Future of Proactive Law: An Overview of the development of the Proactive Law Movement”, in: Berger-Walliser, G. and Østergaard, K. (Eds.), Proactive Law in a Business Environment, DJØF Publishing, pp. 13-32.

Bird, R. (2009), “Law, Strategy and Competitive Advantage 5” (Working Paper Series) available at http://ssrn.com/abstract=1327795

Bowman, C. and Ambrosini, V. (2000), "Value creation versus value capture: towards a coherent definition of value in strategy”, British Journal of Management, Vol. 11 No. 1, pp. 1-15.

Bradach, J. and Eccles, R. (1989), “Price, authority, and trust: from ideal types to plural forms”, Annual Review of Sociology, Vol. 15, pp. 97-118.

Cavusgil, S.T., Yeoh, P.-L. and Mitri, M. (1995), “Selecting Foreign Distributors: An Expert Systems Approach”, Industrial Marketing Management, Vol. 24 No. 4, pp. 297-304.

Chen, P.-Y., Chen, K.-Y. and Wu, L.-Y. (2017), “The impact of trust and commitment on value creation in asymmetric buyer-seller relationships: The mediation effect of specific asset investments”, Journal of Business \& Industrial Marketing, Vol. 32 No. 3.

Crosby, L.A., Evans, K. and Cowles, D. (1990), "Relationship Quality in Services Selling: An Interpersonal Influence Perspective”, Journal of Marketing, Vol. 54 No. 3, pp. 68-81.

Cummins, T. (2015), “Strategic Contracting as a Source of Organizational success”, Journal of Strategic Contracting and Negotiation, Vol. 1, No 1, pp. 7-14.

DiMatteo, L.A. (2010), “Strategic Contracting: Contract Law as a Source of Competitive Advantage”, American Business Law Journal, Vol. 47 No. 4, pp. 727-794. 
DiMatteo, L.A., Siedel, G.J. and Haapio, H. (2012), “Strategic Contracting: Examining the BusinessLegal Interface” in Berger-Walliser, G. and Østergaard, K. (Eds.), Proactive Law in a Business Environment, DJØF Publishing, pp. 59-106.

Dyer, J.H. and Chu, W. (2003), “The role of trustworthiness in reducing transaction costs and improving performance: Evidence from the United States, Japan, and Korea”, Organization Science, Vol. 14 No. 1, pp. 57-68.

Dyer, J.H. and Singh, H. (1998), “The relational view: Cooperative strategy and sources of interorganizational competitive advantage”, Academy of Management Review, Vol. 23 No. 4, pp. 660-679.

Ehret, M. and Haase, M. (2012), “The common ground of relationships and exchange: towards a contractual foundation of marketing”, Journal of Business \& Industrial Marketing, Vol. 27 No. 6, pp. 447-455.

Eisenhardt, K.M. (1989), “Agency Theory: An Assessment and Review”, Academy of Management Review, Vol. 14 No. 1, pp. 57-74.

Ellis, P.D. (2005), “The traders’ dilemma: The adverse consequences of superior performance in mediated exchanges”, International Business Review, Vol. 14, No. 4, pp. 375-396.

Fernie, S. and Metcalf, D. (1999), “It's not what you pay it's the way that you pay it and that's what gets results: Jockeys’ pay and performance”, Labour, Vol. 13 No. 2, pp. 385-411.

Friesen, M.E., Johnson, J.A. (1995), The Success Paradigm: Creating Organizational Effectiveness Through Quality and Strategy. Quorum Books: Westport.

Govindarajan, V. (1988), “A contingency approach to strategy implementation at the business-unit level: integrating administrative mechanisms with strategy”, Academy of Management Journal, Vol. 31 No 4, pp. 828-853.

Gorovaria, N. and Windsperger, J. (2013), "Real Options, Intangible Resources and Performance of Franchise Networks”, Managerial and Decision Economics, Vol. 34 No. 3-5, pp. 183-194. 
Grandinetti, R. (2017), “Exploring the dark side of cooperative buyer-seller relationships”, Journal of Business \& Industrial Marketing, Vol. 32 No. 2.

Gulati, R. (1995), “Does familiarity breed trust? The implications of repeated ties for contractual choice in alliances”, Academy of Management Journal, Vol. 38 No. 1, pp. 85-112.

Heide, J.B. and John, G. (1988), “The Role of Dependence Balancing in Safeguarding TransactionSpecific Assets in Conventional Channels”, Journal of Marketing, Vol. 52 No. 1, 20-35.

Hoetker, G. and Mellevigt, T. (2009), “Choice and performance of governance mechanisms: Matching alliance governance to asset type”, Strategic Management Journal, Vol. 30 No. 10, pp. 10251044.

Holmstrom, B. and Milgrom, P. (1991), “Multitask Principal Agent Analyses - Incentive Contracts, Asset Ownership, and Job Design”, Journal of Law Economics and Organization, Vol. 7 (Special Issue), pp. 24-52.

Hondius, E. and Grigoleit, H.C. (Eds.) (2011) Unexpected Circumstances in European Contract Law, Cambridge University Press.

Hunt, M. (1972), “Competition in the Major Home Appliance Industry”, Doctoral dissertation. Harvard University: Cambridge

IACCM (2011): Top Negotiated Terms. Available at: http://www.iaccm.com/userfiles/docs/top\%20terms\%202011\%201.pdf

IACCM (2013/2014): Top Negotiated Terms. Available at: http://www.iaccm.com/resourcces/?2id=5074

Johanson, J. and Vahlne, J.-E. (1977), “Internationalization process of firm - model of knowledge development and increasing foreign market commitments”, Journal of International Business Studies, Vol. 8 No. 1, pp. 23-32.

Joskow, P.L. (1988), “Asset specificity and the structure of vertical relationships: Empirical evidence”, Journal of Law, Economics, and Organization, Vol. 4, No. 1, pp. 95-117. 
Kahn, L.M. and Sherer, P.D. (1990), “Contingent pay and managerial performance”, Industrial and Labor Relations Review, Vol. 43 No. 3, pp. 107-20.

Karanuratna, A.R. and Johnson, L.W. (1997), "Initiating and maintaining export channel intermediary relationships”, Journal of International Marketing, Vol. 5 No. 2, pp. 11-32.

Katsikeas, C.S., Samiee, S. and Theodosiou, M. (2006), "Strategy fit and performance consequences of international marketing standardization”, Strategic Management Journal, Vol. 27 No. 9, pp. 867890.

Klein, B., Crawford, R.G. and Alchian, A.A. (1978), "Vertical Integration, Appropriable Rents, and the Competitive Contracting Process”, The Journal of Law and Economics, Vol. 21 No. 2, pp. 297326.

Lawrence, P. and Lorsch, J. (1967), "Differentiation and integration in complex organizations. Administrative Science Quarterly, Vol. 12 No. 1, pp. 1-30.

Li, L. (2003), “Joint effects of factors affecting exchanges between exporters and their foreign intermediaries: an exploratory study”, Journal of Business \& Industrial Marketing, Vol.18 No.2, pp. 162-178.

Li, J.J., Poppo, L. and Zhou, K.Z. (2010), “Relational mechanisms, formal contracts, and local knowledge acquisition by international subsidiaries”, Strategic Management Journal, Vol. 31, No 4, pp. 349-370.

Lieberman, M.B. and Montgomery, D.B. (1988), “First-Mover advantages”, Strategic Management Journal, Vol. 19 (Special Issue), pp. 41-58.

Leonidou, L.C., Barnes, B.R. and Talias, M.A. (2006), “Exporter-Importer relationship quality: The inhibiting role of uncertainty, distance, and conflict”, Industrial Marketing Management, Vol. 35 No. 5, pp. 576-588.

Macauley, S. (1963), “Non-Contractual Relations in Business: A Preliminary Review”, American Sociology Review, Vol. 28, pp. 55-67. 
Macneil, I.R. (1978), “Contracts: adjustment of long-term economic relations under classical, neoclassical and relational contract law”, Northwestern University Law Review, Vol. 72 No. 6, pp. 854-902.

Macneil, I.R. (2000), “Relational contract theory: challenges and queries”, Northwestern University Law Review, Vol. 94 No. 3, pp. 877-907.

McGee, J. and Thomas, H. (1986), “Strategic groups: theory, research and taxonomy”, Strategic Management Journal, Vol. 7 No. 2, pp. 141-160.

McVey, P. (1960), “Are Channels of Distribution What the Textbooks Say?”, Journal of Marketing, Vol. 24 (January), pp. 1-64.

Mellevigt, T., Madhok, A. and Weibel, A. (2007), “Trust and formal contracts in interorganizational relationships - Substitutes and complements”, Managerial and Decision Economics, Vol. 28 No. 8, pp. 833-847.

Mintzberg, H. (1979), The Structuring of Organizations. Prentice-Hall: New York.

Mouzas, S. and Blois, K. (2013), “Contract research today: where do we stand?”, Industrial Marketing Management, Vol. 42 No. 7, pp. 1057-1062.

Mouzas, S. and Ford, D. (2012), “Contracts as a facilitator of resource evolution”, Journal of Business Research, Vol. 65 No. 9, pp. 1251-1253.

Möhring, M.M. and Finch, J. (2013), “Contracts, relationships and innovation in business-to-business exchanges”, Journal of Business \& Industrial Marketing, Vol. 30 No. 3-4, pp. 405-413.

Naude, P. and Buttle, F. (2000), “Assessing relationship quality”, Industrial Marketing Management, Vol. 29 No. 4, pp. 351-361.

Perrow, C. (1967), “A framework for the comparative analysis of organizations”, American Sociological Review, Vol. 32, pp. 194-208.

Petersen, B. (1996), Explaining Cost-effective Export Market Penetration via Foreign Intermediaries. PhD Dissertation, Copenhagen Business School PhD Series 4.96. 
Petersen, B., Pedersen, T. and Benito, G.R.G. (2000), "Replacing the Foreign Intermediary: Motivators and Deterrents”, International Studies of Management and Organization, Vol. 30 No. 1, pp. 4764.

Petersen, B., Pedersen, T. and Benito, G.R.G. (2006), “The Termination Dilemma of Foreign Intermediaries: Performance, Anti-shirking Measures and Hold-up Safeguards”, Advances of International Marketing, Vol. 16, pp. 317-339.

Petersen, B., Welch, D.E. and Welch, L.S. (2000), “Creating Meaningful Switching Options in International Operations”, Long Range Planning, Vol. 33 No. 5, pp. 690-707.

Poppo, L. and Zenger, T. (2002), "Do formal contracts and relational governance function as substitutes or complements?”, Strategic Management Journal, Vol. 23 No. 8, pp. 707-725.

Porter, M.E. (1980), Competitive Strategy. New York: The Free Press.

Posner, R.A. (2007), Economic Analysis of Law (7 $7^{\text {th }}$ ed.). Austin, TX: Wolters Kluwer.

Reddy, N.M. and Marvin, M.P. (1986), “Developing a Manufacturer-Distributor Information Partnership”, Industrial Marketing Management, Vol. 15 No. 2, pp. 157-163.

Rumelt, R.P. (2011), Good Strategy - Bad Strategy. The Difference and Why It Matters. Crown Publishing Group, Random House, Inc., New York.

Samiee, S. and Walters, P.G.P. (2003), "Relationship marketing in an international context: A literature review”, International Business Review, Vol. 12 No. 2, pp. 193-214.

Sharma, A. and Sheth, J.N. (1997), “Relationship marketing: An agenda for inquiry”, Industrial Marketing Management, Vol. 26 No. 2, pp. 87-89.

Shavell, S. (1979), "Risk sharing and incentives in the principal and agent relationship”, The Bell Journal of Economics, Vol. 10 No. 1, pp. 55-73.

Simon, H.A. (1956), "Rational Choice and the Structure of the Environment”, Psychological Review, Vol. 63 No. 2, pp. 129-138. 
Skarmeas, D., Katsikeas, C.S., Spyropoulou, S. and Salehi-Sangari, E. (2008), "Market and supplier characteristics driving distributor relationship quality in international marketing channels of industrial products”, Industrial Marketing Management, Vol. 37 No. 1, pp. 23-36.

Schepker, D.J., Oh, W.-Y., Martynov, A. and Poppo, L. (2014), “The Many Futures of Contracts: Moving Beyond Structure and Safeguarding to Coordination and Adaptation”, Journal of Management, Vol. 40 No. 1, pp. 193-225.

Spence, M. (1973), “Job Market Signaling”, Quarterly Journal of Economics, Vol. 87 No. 3, pp. 355374.

Stabell, C.B. and Fjeldstad, Ø.D. (1998), “Configuring value for competitive advantage: On chains, shops, and networks”, Strategic Management Journal, Vol. 19 No. 5, pp. 413-437.

Stinchcombe, A.L. (2001), When formality works, Chicago and London: The University of Chicago Press.

Thompson, J.D. (1967), Organizations in Action. McGraw-Hill: New York.

Triantis, G.G. (2000), “Unforeseen Contingencies. Risk Allocation in Contracts”, in Bouckaert, B. and de Geest, G. (Eds.), Encyclopedia of Law and Economics. Cheltenham, UK: Edward Elgar.

Tsay, A.A. and Agrawal, N. (2004), “Channel Conflict and Coordination in the E-Commerce Age”, Production \& Operations Management, Vol. 13 No. 1, pp. 93-110.

Walter, A., Muller, T.A., Helfert, G. and Ritter, T. (2003), “Functions of industrial supplier relationships and their impact on relationship quality”, Industrial Marketing Management, Vol. 32 No 2, pp. 159-169.

Wathne, K.H. and Heide, J.B. (2000), “Opportunism in interfirm relationships: forms, outcomes, and solutions”, Journal of Marketing, Vol. 64 No. 4, pp. 36-51.

Webster, Jr F. (1976), “The Role of the Industrial Distributor in Marketing Strategy”, Journal of Marketing, Vol. 40 No. 3, pp. 10-16. 
Weiss, A.M. and Anderson, E. (1992), “Converting From Independent to Employee Salesforce: The Role of Perceived Switching Costs”, Journal of Marketing Research, Vol. 29 No. 1, pp. 101-115.

Weiss, A.M. and Kurland, N. (1997), “Holding Distribution Channel Relationships Together: The Role of Transaction-Specific Assets and Length of Prior Relationship”, Organization Science, Vol. 8 No. 6, pp. 612-623.

Welch, L.S., Benito, G.R.G. and Petersen, B. (2007), Foreign Operation Methods: Analysis, Strategy, and Dynamics. London: Edward Elgar.

Williamson, O.E. (1983), “Credible commitments: Using hostages to support exchange”, The American Economic Review, Vol. 73 No. 4, pp. 519-540.

Williamson, O.E. (1985), The Economic Institutions of Capitalism. Free Press, New York NY.

Woodward, J. (1958), Management and Technology. Her Majesty's Stationery Office: London.

Yang, P., Qian, L. and Zheng, S. (2017), “Improving performance and curtailing opportunism: the role of contractual issue inclusiveness and obligatoriness in channel relationships”, Journal of Business \& Industrial Marketing, Vol. 32 No. 3, pp. 371-384.

Zhang, C., Cavusgil, S.T. and Roath, A.S. (2003), "Manufacturer governance of foreign distributor relationships: Do relational norms enhance competitiveness in the export market?”, Journal of International Business Studies, Vol. 34 No. 6, pp. 550-556.

Zaheer, A. and Venkatraman, N. (1995), "Relational Governance as an Interorganizational Strategy: An Empirical Test of the Role of Trust in Economic Exchange”, Strategic Management Journal, Vol. 16, No 5. , pp. 373-392.

Zeithaml, V., Varadarajan, P.R. and Zeithaml, C.P. (1988), “The contingency approach: its foundations and relevance to theory building and research in marketing”, European Journal of Marketing, Vol. 22 No. 7, pp. 37-64. 


\section{Table I: Objectives and means of conventional contracting and strategic contracting}

\begin{tabular}{|c|c|c|c|c|}
\hline \multirow{2}{*}{ DIMENSION } & \multicolumn{2}{|c|}{$\begin{array}{l}\text { CONVENTIONEL } \\
\text { CONTRACTING }\end{array}$} & \multicolumn{2}{|c|}{$\begin{array}{l}\text { STRATEGIC } \\
\text { CONTRACTING }\end{array}$} \\
\hline & OBJECTIVE & MEANS & OBJECTIVE & MEANS \\
\hline $\begin{array}{l}\text { Choice of } \\
\text { intermediary }\end{array}$ & $\begin{array}{l}\text { To appoint, at low or } \\
\text { no search costs, an } \\
\text { acceptable } \\
\text { intermediary }\end{array}$ & $\begin{array}{c}\text { Appointment of } \\
\text { intermediary on the } \\
\text { basis of self-selection }\end{array}$ & $\begin{array}{l}\text { To appoint the best } \\
\text { possible intermediary }\end{array}$ & $\begin{array}{l}\text { Appointment of inter- } \\
\text { mediary on the basis of } \\
\text { signaling and screening }\end{array}$ \\
\hline $\begin{array}{c}\text { Collaborative } \\
\text { basis }\end{array}$ & $\begin{array}{l}\text { Goal congruence in } \\
\text { terms of expected } \\
\text { sales in territory }\end{array}$ & $\begin{array}{l}\text { Requirements for } \\
\text { minimum sales as } \\
\text { redeemable clause }\end{array}$ & $\begin{array}{l}\text { Strategic fit with } \\
\text { intermediary }\end{array}$ & $\begin{array}{l}\text { Developing and } \\
\text { committing to a joint } \\
\text { business plan }\end{array}$ \\
\hline $\begin{array}{l}\text { Commercial risk } \\
\text { allocation }\end{array}$ & $\begin{array}{l}\text { Minimization of own } \\
\text { commercial risk }\end{array}$ & $\begin{array}{l}\text { Outcome-based } \\
\text { remuneration of } \\
\text { intermediary }\end{array}$ & $\begin{array}{l}\text { Risk allocation based } \\
\text { on the parties' risk } \\
\text { tolerance }\end{array}$ & $\begin{array}{l}\text { Behavior-based } \\
\text { remuneration of } \\
\text { intermediary }\end{array}$ \\
\hline Commitment & $\begin{array}{l}\text { Lowest possible } \\
\text { costs in case of } \\
\text { contract termination }\end{array}$ & $\begin{array}{l}\text { Ensuring trademarks } \\
\text { and disclaiming good- } \\
\text { will compensation }\end{array}$ & $\begin{array}{l}\text { Value creation via } \\
\text { relationship-specific } \\
\text { investments }\end{array}$ & $\begin{array}{l}\text { Putting in place safe- } \\
\text { guards against hold-up } \\
\text { and free-riding }\end{array}$ \\
\hline $\begin{array}{l}\text { Conflict } \\
\text { resolution }\end{array}$ & $\begin{array}{l}\text { Re-active dispute } \\
\text { resolution by third } \\
\text { party }\end{array}$ & $\begin{array}{l}\text { Refer disputes to } \\
\text { court decision or } \\
\text { arbitration }\end{array}$ & $\begin{array}{l}\text { Prevent disputes } \\
\text { through private } \\
\text { ordering }\end{array}$ & $\begin{array}{l}\text { Putting in place pro- } \\
\text { active remedies }\end{array}$ \\
\hline
\end{tabular}




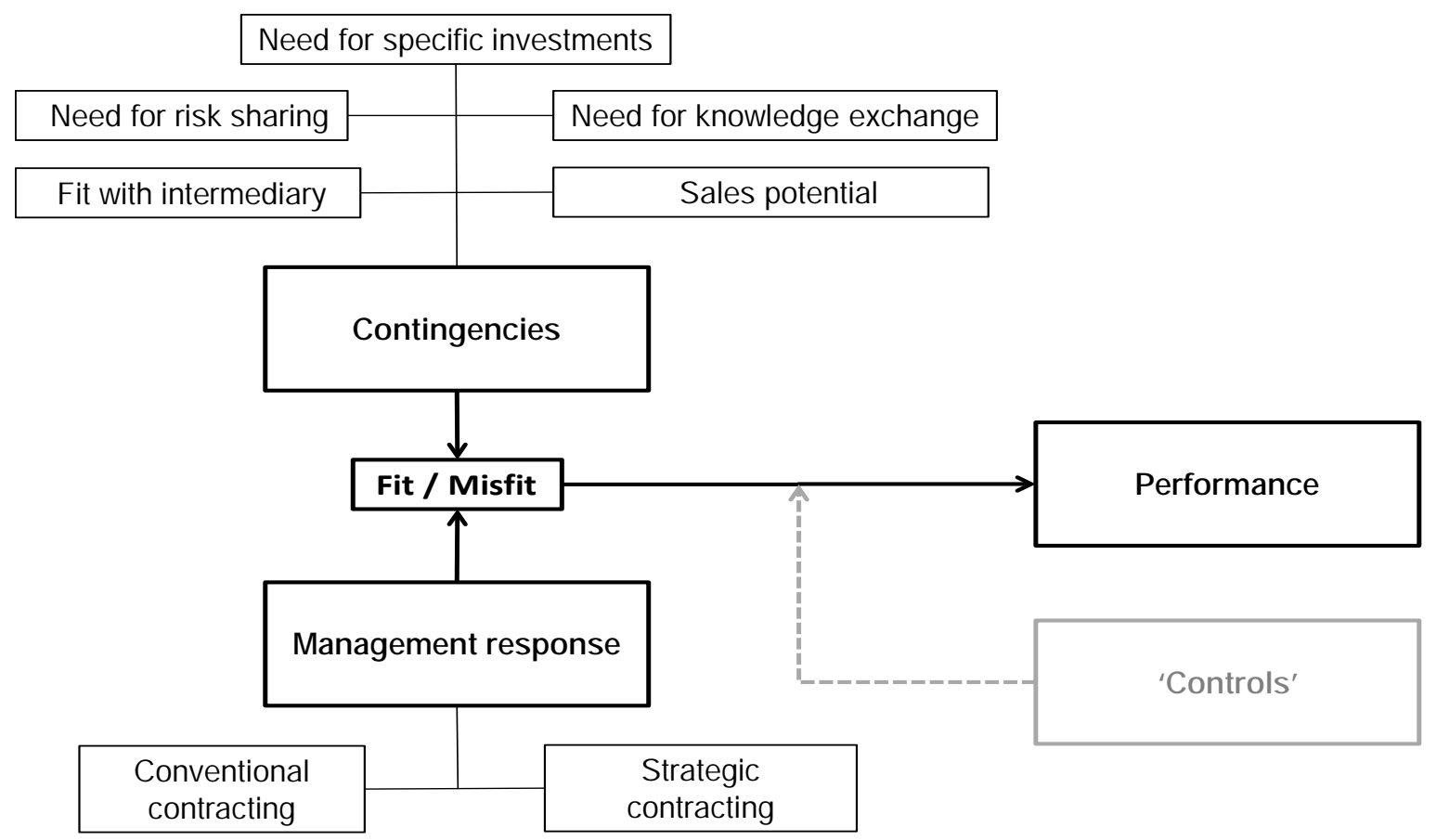

Figure 1: A contingency approach to the contracting choice 


\section{Endnotes}

${ }^{1}$ This wording is taken from a model distributor contract used by a multinational manufacturer of food products. Notably, in the 2011 IACCM (International Association for Contract and Commercial Management) survey, “scope and goals” and "responsibilities of the parties” appeared as two of the four terms considered most productive in supporting successful relationships. However, neither of these two terms is on the top-ten list of terms that are negotiated with greatest frequency in the surveys from 2011 or 2013/2014 (IACCM, 2011, IACCM 2013/2014).

${ }^{2}$ Cases in which the intermediary's relationship-specific investments are matched by the manufacturer are already accounted for in the description of direct, specific investments by the manufacturer. Therefore, this “exchange of hostage” situation (Williamson, 1983) is not subject to further review.

${ }^{3}$ In many jurisdictions, the legal solution to an unexpected circumstance is not necessarily the best economic solution, as in many cases it implies the dissolution of the contract. The court, depending on the jurisdiction, might apply the default rules of force majeure, the doctrine of assumptions, the principle of unfair contract terms, the principle that the closest party bears the risk, or the principle of in dubio contra stipulatorem. The latter principle is traditionally used to interpret the contract against the party who has drawn up the contract. For additional information, see Hondious and Grigoleit (2011). 